\title{
Comparing perceptions of climate-related environmental changes for Tuvalu, Samoa, and Tonga
}

\author{
Katharina Beyerl, Harald A. Mieg, and Eberhard H. Weber
}

\begin{abstract}
Individual perceptions of climate-related environmental changes are essential to understand behavioural responses to such changes. Despite several studies on change-perception in single Pacific Small Island States (PSIS), the variance in these perceptions within and between different PSIS has so far largely been neglected. We, therefore, explored perceptions of climate-related environmental changes and attributed causes in Tuvalu, Samoa, and Tonga. Our survey $(\mathrm{N}=180)$ shows that perceptions of environmental changes vary considerably between the three island states and also within each country. A certain fraction of this variance can be explained by (i) geographical and climatic differences between the island states and (ii) selected socio-demographic variables. The socio-demographic factors that proved most relevant include (i) the size of the settlement in which respondents live, (ii) their distance to the sea, (iii) their interaction with nature, and (iv) their self-assessment of their own religiosity. Moreover, we found that people attribute reported changes to manifold irresponsible and unsustainable human behaviours, and to a lesser extent to natural processes and divine acts. By illustrating the variance of perceptions and also the awareness of anthropogenic causes, the study helps to communicate the diversity of local voices and offers ways for finding a basis for discussing and implementing more sustainable behaviour alternatives.
\end{abstract}

Cite this article: Beyerl, K., Mieg, H.A., \& Weber, E. (2019): Comparing perceptions of climaterelated environmental changes for Tuvalu, Samoa, and Tonga. In: Klöck, C. \& Fink, M. (eds.): Dealing with climate change on small islands: Towards effective and sustainable adaptation? (pp. 143-174). Göttingen: Göttingen University Press. https://doi.org/10.17875/gup2019-1215 


\section{$1 \quad$ Introduction}

How people perceive their natural and social environment is key to how they behave in order to address the situations they are confronted with (Beyerl, Putz, \& Breckwoldt, 2016). The experience of seasonal cycles, for instance, and the way humans have learned to adapt to them over time, shapes our behaviours not only with regard to clothing and indoor and outdoor activities for daily subsistence or leisure, but also with regard to how we maintain buildings that protect us from the elements. We have adapted our behavioural patterns and infrastructures to the familiar variability of environmental conditions, and to a certain degree we are prepared for occasional extreme weather events. Based on our experiences we also plan and lay the foundations for the future, trying to ensure our own wellbeing and that of our loved ones. As anywhere else in the world, people in tropical Pacific Small Island States (PSIS) have adapted to their environment. However, climaterelated environmental changes are projected to alter familiar conditions and challenge the adaptive capacity of people and ecosystems (Nunn, 2009).

Many studies have investigated the vulnerability of PSIS to climate change from the perspective of the natural sciences and focused on potential implications for infrastructure, economy, and migration (e.g. Keener, Marra, Finucane, Spooner, \& Smith, 2012; Nunn, 2013; Nurse et al., 2014; Australian Bureau of Meteorology \& CSIRO 2011, 2014; SPREP, 2016). But apart from a few exceptions (e.g. Kuruppu \& Liverman, 2011; Lata \& Nunn, 2012; Roudiak-Gould, 2012, 2014; Nunn et al., 2016), reports that go beyond anecdotal evidence of how these changes are perceived by the affected populations are largely still missing in the peer-reviewed literature (Betzold, 2015). Even for Tuvalu, which is often described as one of the most prominent examples of a Small Island State facing climate change and the threat of becoming uninhabitable in the near future (Farbotko, 2010), peerreviewed perception research is rare, and statistically usable data regarding people's perception of environmental changes is hardly available.

In order to better support the planning of adaptation strategies, awarenessraising programs, and the implementation of effective precautionary measures, it is crucial to be aware of how people perceive the situation that needs to be addressed (Beyerl, Mieg, \& Weber, 2018). Simply put, if people do not notice adverse change, they might not see any need to do something about it. And even if they perceive certain changes, their attribution of the relevant causes can vary, and can lead to behaviours that are not necessarily optimal options for mitigation and adaptation (Beyerl et al., 2016; Grothmann \& Patt, 2005).

Because of their relatively small land sizes, combined with political independence, the multitude of occurring and projected environmental changes, and the specific nature-dependency of their inhabitants, PSIS are a special region to study perceptions of climate-related changes. Moreover, the combination of a historically grown culture of long-term subsistence with the increasing prevalence of modern, unsustainable lifestyles makes PSIS particularly interesting examples of how envi- 
ronmental change and its reasons are perceived in times of the global socioecological crisis.

For many PSIS, information about people's perceptions and interpretations is still missing, and systematic ways of recording and sharing local observations are required, so that results can be compared across locations to inform adaptive management (McMillen et al., 2014). As a contribution to closing this gap for three of these countries, this study reports survey results from Tuvalu, Samoa, and Tonga relating to the following research questions: (i) What kind of climate-related environmental changes do people perceive? (ii) What do respondents think are the causes of the reported changes? (iii) Are there overarching correlational patterns for environmental perceptions and selected socio-demographic variables that can help explain potential variance in perceptions?

\section{Geographical characteristics and climate features of Tuvalu, Samoa, and Tonga}

Tuvalu, Samoa, and Tonga are PSIS located in the tropics and are representative examples of the main geological formations of island types in the Pacific Island region (Barnett \& Campell, 2010). While they share certain characteristics as island states, they differ in their geographical and climatic features (Table 1). Whereas Tuvalu is comprised of nine narrow coral atolls with maximum heights above sea level of only $5 \mathrm{~m}$, Tonga numbers 177 islands of which some are low-lying coral formations and others are of volcanic origin with maximum elevations above sea level of $1,033 \mathrm{~m}$. The independent state of Samoa is comprised of two large main islands of volcanic origin with narrow coastal plains and interior mountains of up to 1,857 m height, and eight smaller islands, of which only two are inhabited. The island topography also affects weather patterns, with higher mountains fostering orographic rainfall, whereas coral atoll islands depend on convective rain (Terry, 2007).

Table 1: Geographical features, current climate characteristics, and climate projections until 2100 from Funafuti for Tuvalu, Apia for Samoa, and Nuku'alofa for Tonga (Australian Bureau of Meteorology \& CSIRO, 2011, 2014; SPC, 2018; Barnett \& Campbell, 2010).

\begin{tabular}{l|c|c|c}
\hline $\begin{array}{l}\text { Regional } \\
\text { characteristics }\end{array}$ & Tuvalu & Samoa & Tonga \\
\hline Land area & $26 \mathrm{~km}^{2}$ & $2,934 \mathrm{~km}^{2}$ & $749 \mathrm{~km}^{2}$ \\
\hline $\begin{array}{l}\text { Number } \text { of } \\
\text { inhabitants }\end{array}$ & 10,200 & 196,700 & 100,300 \\
\hline Topography & $\begin{array}{l}\text { Low-lying and narrow } \\
\text { coral atolls }\end{array}$ & $\begin{array}{l}\text { Narrow coastal plains, } \\
\text { interior mountains }\end{array}$ & $\begin{array}{l}\text { Coral formation, } \\
\text { Volcanic }\end{array}$ \\
\hline $\begin{array}{l}\text { Highest } \\
\text { elevation }\end{array}$ & $5 \mathrm{~m}$ & $1,857 \mathrm{~m}$ & $1,033 \mathrm{~m}$ \\
\hline
\end{tabular}




\begin{tabular}{|c|c|c|c|}
\hline \multicolumn{4}{|c|}{ Current climate } \\
\hline $\begin{array}{l}\text { Air } \\
\text { temperature }\end{array}$ & $\begin{array}{l}\text { Air temperatures are } \\
\text { relatively constant } \\
\text { throughout the year and } \\
\text { closely related to sea- } \\
\text { surface temperatures }\end{array}$ & $\begin{array}{l}\text { Very small seasonal } \\
\text { temperature differences }\end{array}$ & $\begin{array}{l}\text { Seasonal variations in } \\
\text { air temperature due to } \\
\text { position close to sub- } \\
\text { tropics, partly driven by } \\
\text { sea-surface temperature } \\
\text { of the oceans }\end{array}$ \\
\hline Rainfall & $\begin{array}{l}\text { - Wet season from } \\
\text { November to April } \\
\text { - Dry season from May } \\
\text { to October } \\
\text { - Strong seasonal cycle } \\
\text { driven by the strength of } \\
\text { SPCZ } \\
\text { - High year-to-year } \\
\text { variability due to the } \\
\text { impact of ENSO }\end{array}$ & $\begin{array}{l}\text { - Wet season from } \\
\text { November to April } \\
\text { - Rainfall greatly influ- } \\
\text { enced by the position } \\
\text { and strength of SPCZ } \\
\text { - Significant year-to- } \\
\text { year variability influ- } \\
\text { enced by ENSO }\end{array}$ & $\begin{array}{l}\text { - Wet season from } \\
\text { November to April } \\
\text { with two thirds of the } \\
\text { annual rainfall; } \\
\text { - High year-to-year } \\
\text { variability due to } \\
\text { ENSO }\end{array}$ \\
\hline $\begin{array}{l}\text { During } \\
\text { El Niño }\end{array}$ & $\begin{array}{l}\text { - Wet } \\
\text { - Lower than normal sea } \\
\text { level }\end{array}$ & $\begin{array}{l}\text { - Dry } \\
\text { - Lower than normal } \\
\text { sea level }\end{array}$ & $\begin{array}{l}\text { - Dry, in extreme years } \\
\text { very dry }\end{array}$ \\
\hline $\begin{array}{l}\text { During } \\
\text { La Niña }\end{array}$ & $D_{1}$ & $\begin{array}{l}\text { - No consistent impact } \\
\text { on rainfall; } \\
\text { - Higher than normal } \\
\text { sea level }\end{array}$ & Wet \\
\hline \multirow{2}{*}{$\begin{array}{l}\text { Tropical } \\
\text { cyclones }\end{array}$} & $\begin{array}{l}\text { On average } 8 \text { tropical } \\
\text { cyclones per decade }\end{array}$ & $\begin{array}{l}\text { On average } 10 \text { tropical } \\
\text { cyclones per decade }\end{array}$ & $\begin{array}{l}\text { On average } 17 \text { tropical } \\
\text { cyclones per decade }\end{array}$ \\
\hline & \multicolumn{3}{|c|}{$\begin{array}{l}\text { Most cyclones usually occur between November and April, with high inter- } \\
\text { annual variability. }\end{array}$} \\
\hline Curr & \multicolumn{3}{|c|}{$\begin{array}{l}\text { Warming trends in annual and seasonal mean air temperatures for the period } \\
1950-2009 \text {; } \\
\text { Annual and seasonal rainfall trends for the period 1950-2009 not statistically } \\
\text { significant }\end{array}$} \\
\hline Ten & $\begin{array}{l}\text { - Significant increases in } \\
\text { warm nights } \\
\text { - Significant decreases in } \\
\text { cool nights }\end{array}$ & $\begin{array}{l}\text { - Annual number of } \\
\text { cool days has decreased } \\
\text { significantly }\end{array}$ & $\begin{array}{l}\text { (Insufficient daily } \\
\text { temperature data) }\end{array}$ \\
\hline Se & $\begin{array}{l}\text { - about } 5 \mathrm{~mm} / \text { year near } \\
\text { Tuvalu measured by } \\
\text { satellite altimeters since } \\
1993\end{array}$ & $\begin{array}{l}\text { - about } 4 \mathrm{~mm} / \text { year near } \\
\text { Samoa measured by } \\
\text { satellite altimeters since } \\
1993\end{array}$ & $\begin{array}{l}\text { - over } 6 \mathrm{~mm} / \text { year near } \\
\text { Tonga measured by } \\
\text { satellite altimeters since } \\
1993\end{array}$ \\
\hline
\end{tabular}

\section{Future projections}

E1 Niño and El Niño and La Niña events will continue to occur in the future (very high La Niña $\quad$ confidence), but there is little consensus on whether these events will change in intensity or frequency.

Air $\quad$ Annual mean temperatures and extremely high daily temperatures will con-

Temperature tinue to rise (very high confidence). 


\begin{tabular}{|c|c|c|c|}
\hline Rainfall & $\begin{array}{l}\text { - Not clear whether } \\
\text { mean annual rainfall will } \\
\text { increase or decrease, } \\
\text { model average indicating } \\
\text { little change, with more } \\
\text { extreme rain events. } \\
\text { - Incidence of drought is } \\
\text { projected to decrease } \\
\text { slightly. }\end{array}$ & $\begin{array}{l}\text { - Little change in mean } \\
\text { annual rainfall is pro- } \\
\text { jected (low confidence), } \\
\text { with more intense and } \\
\text { frequent extreme rain events } \\
\text { (high confidence). } \\
\text { - Incidence of drought } \\
\text { is projected to decline } \\
\text { or stay approximately } \\
\text { the same (low confi- } \\
\text { dence). }\end{array}$ & $\begin{array}{l}\text { - Not clear whether } \\
\text { mean annual rainfall } \\
\text { will increase or decrease } \\
\text { and the model average } \\
\text { indicates little change } \\
\text { with more extreme rain } \\
\text { events. } \\
\text { - Drought frequency is } \\
\text { projected to decrease } \\
\text { slightly. }\end{array}$ \\
\hline $\begin{array}{l}\text { Sea level, } \\
\text { wave heights, } \\
\text { ocean acidifi- } \\
\text { cation }\end{array}$ & \multicolumn{3}{|c|}{$\begin{array}{l}\text { Sea level will continue to rise. Ocean acidification is expected to continue. The } \\
\text { risk of coral bleaching is expected to increase. (Very high confidence for all.) }\end{array}$} \\
\hline & $\begin{array}{l}\text { December-March wave } \\
\text { heights and periods are } \\
\text { projected to decrease } \\
\text { slightly }\end{array}$ & $\begin{array}{l}\text { A reduction of wave } \\
\text { period in December- } \\
\text { March is projected with } \\
\text { no change in wave } \\
\text { height (low confi- } \\
\text { dence), while no change } \\
\text { is projected in June- } \\
\text { September (low confi- } \\
\text { dence). }\end{array}$ & $\begin{array}{l}\text { December-March wave } \\
\text { heights and periods are } \\
\text { projected to decrease } \\
\text { slightly. }\end{array}$ \\
\hline Cyclones & \multicolumn{3}{|c|}{ Tropical cyclones are projected to be less frequent but more intense. } \\
\hline
\end{tabular}

The main climate features affecting the island groups are the El Niño-Southern Oscillation (ENSO), the West Pacific Monsoon, the South Pacific Convergence Zone (SPCZ), trade winds, sub-tropical highs, and tropical cyclones (Australian Bureau of Meteorology \& CSIRO, 2011, 2014). In particular, ENSO causes great variability in yearly climate features. In El Niño years, the weather in Samoa and Tonga tends to be dryer with lower than average sea levels, whereas in Tuvalu the weather tends to be wetter. For La Niña years, the opposite is the case, with dryer conditions in Tuvalu, wetter weather in Tonga, and higher than normal sea levels in Samoa. In extreme years, ENSO conditions can lead to severe droughts (as in 2011) or to flooding respectively. In addition, tropical cyclones are common, whose strong and destructive winds accompanied by heavy rainfall and high waves frequently lead to flooding with rain water and sea water.

With regard to temperature, rain, and wind, the three countries differ slightly. Temperatures are relatively constant in Tuvalu and Samoa, but show some annual variation in Tonga. Similar for all three countries is the very high inter-annual variability of rainfall and the occurrence of tropical cyclones. In all three states, the wet(ter) season usually prevails from November until April, and the dry(er) season from May to October. According to reports of the Australian Bureau of Meteorology and CSIRO $(2011,2014)$, current climate trends indicate warming of the annual and seasonal mean air temperatures for the period of 1950 to 2009. The number of cool nights and days are decreasing, whereas warm nights and days show in- 
creasing trends. Furthermore, satellite altimeters show increases in sea level of about 4-6 mm per year since 1993 .

As reported by the Australian Bureau of Meteorology and CSIRO (2011, 2014), CMIP5 climate models project that annual mean temperatures and extremely high daily temperatures will continue to rise. Also, extreme precipitation events are expected to increase, whereas the occurrence of droughts is projected to decrease slightly. However, the models' confidence levels for drought events are rather low. With respect to storms, it is notable that tropical cyclones are projected to be less frequent but more intense. With very high confidence though, models agree in their projections that the sea level will continue to rise, oceans will get warmer and more acidic, and the risk of coral bleaching will increase.

Despite the relative smallness of the three island states, there are always local specificities that need to be considered in detail (Nunn \& Kumar, 2018; Betzold \& Magnan, 2019). Not only can extreme events affect some parts of an archipelago while leaving other parts without greater harm, but also vulnerabilities, resilience, and adaptive capacity can vary substantially between places. Therefore, the descriptions above should be seen as approximate characteristics. Moreover, specific climate data for remote places and communities is not always available.

\section{Perception of climate-related environmental changes}

In the context of the advancing debate on climate change, the perception of weather and environmental changes has received increased attention during the past years (Savo et al., 2016). Simultaneously, numerous studies have investigated the perception of global climate change or global warming (Wolf \& Moser, 2011; Capstick, Whitmarsh, Poortinga, Pidgeon, \& Upham, 2015). Although seemingly similar at first glance, the two branches of research differ in several aspects. Indepth research about the perception of weather anomalies and climate-related environmental changes often tries to find out what kind of changes people perceive, compares the results with scientific measurement data, and links perceptions to traditional ecological knowledge, societal change, cultural practice, and adaptation behaviour (Aswani, Vaccaro, Abernethy, Albert, \& Fernandez, 2015; Green, Billy, \& Tapim, 2010; West, Roncoli, \& Ouattara, 2008; Vedwan \& Rhoades, 2001). Surveys about public perception of climate change and global warming, however, focus more on capturing attitudes towards a relatively abstract statistical construct and consequent behavioural responses, and try to explain the interindividual variance by investigating relations to socio-demographic, cognitive, experiential, and socio-cultural factors (Weber, 2016; van der Linden, 2015). Studies of the first kind have been conducted in many parts of the world, mainly in Africa and Asia (Savo et al., 2016). Studies of the latter kind are often based on large scale public opinion surveys carried out particularly in the United States, European countries, Canada, Australia, and New Zealand (Wolf \& Moser, 2011; Capstick et 
al., 2015; Leiserowitz, Maibach, Roser-Renouf, Feinberg, \& Rosenthal, 2016; Reser, Bradley, Glendon, Ellul, \& Callaghan, 2012; Pidgeon, 2012; Lorenzoni \& Pidgeon, 2006; Milfont, Milojev, Greaves, \& Sibley, 2015; Bord, Fisher, \& O’Connor, 1998; for international comparisons see Lee, Markowitz, Howe, Ko, \& Leiserowitz, 2015; Brechin \& Bhandari, 2011). Both approaches have their strengths. In-depth studies often put emphasis on the variety of potentially perceivable environmental changes and socio-environmental interdependencies, yet focus less on explaining inter-individual differences. Survey studies investigate a multitude of factors that affect the variance in perceptions, yet often reduce climate change experience to few specific climate-related features, such as air temperature anomalies, extreme events (floods, droughts, and storms), or general experience (Reser, Bradley, \& Ellus, 2014).

Main results of both types of studies are summarised in Table 2. In order to grasp the different kinds of climate-related environmental changes that are found to be perceived, an extensive review of observations among subsistence-oriented communities around the world reveals that alterations have been reported for weather, as well as for components in the biotic and abiotic environment (Savo et. al., 2016). Results of studies that try to explain the variance in climate change (risk) perception and awareness identify socio-demographic, cognitive, experiential, and socio-cultural factors (van der Linden, 2015; Milfont et al., 2015; Lee et al., 2015; Whitmarsh, 2011).

Table 2: Results of in-depth and survey studies around the world regarding the types of perceived climate-related environmental changes (A; Savo et al., 2016) and factors explaining the variance in such perceptions (B; van der Linden, 2015; Milfont et al., 2015).

(A) climate-related environmental changes observed around the world

\section{Weather and climate}

changes in rainfall; temperature; seasonality and predictability of weather; drought; extreme weather events incl. heavy rainfall; storms and hurricanes

\footnotetext{
Abiotic environment

reduction of freshwater availability; increases in the frequency and severity of floods and landslides; sea level rise

Impacts on biological systems decreases in crop production; changes in species ranges; alterations in the timing and fruiting of wild and cultivated plants
}

(B) factors explaining variance in perceptions of climate change

Socio-demographic factors

age; gender; education; socio-economic status

\section{Socio-cultural factors}

culture; values (egoistic, socio-altruistic, biospheric); worldviews (egalitarianism, individualism, hierarchism, and fatalism); religious beliefs; social norms

\section{Cognitive factors}

knowledge about causes, impacts, and responses; biases and heuristics; sense of control; psychological distance

\section{Experiential factors}

affect; personal experience (direct and mediated) 
In particular, there is a general effect of personal experience for the perception of changes in weather and nature (Marx et al., 2007; Reser et al., 2014; van der Linden, 2015; Weber, 2016). On the one hand, personal experience can be rather direct through personal observation - for instance, people living close to the sea show a different perception of sea level rise and climate change than those living further inland (Milfont, Evans, Sibley, Ries, \& Cunningham, 2014). On the other hand, personal experience can be mediated through communication - here, the access to information and media is crucial and influences how people are informed about climate change science (Roudiak-Gould, 2013). Access to information varies around the world within and between countries, suggesting that people from rural areas with less access might perceive climate-related environmental change differently compared to those in larger settlements. In addition, the size of a settlement that someone lives in might impact their perception considerably due to different environmental pressures as well as other types of employment (e.g. service industries in cities vs. jobs in farming and fishing in rural communities). Moreover, perceptions of change are likely to be affected by property situations as people who own their house and land, for instance, bear not only responsibility for their property but also have a considerable interest in its intactness (Grothmann, 2005).

For PSIS, there have been several studies reporting environmental changes that people perceive, and more recent surveys also focus on university students' perceptions of climate change in a broader sense; however, the potential variance in these perceptions particularly for non-student samples has hardly been addressed (Lazrus, 2015; Kuruppu \& Liverman, 2011; Roudiak-Gould, 2012, 2014; Aswani et al., 2015). In the present study, we therefore attempt to combine the two approaches and compare three Polynesian countries in order to answer the research questions about people's perceptions of climate-related environmental changes, views on potential causes for these changes, and correlational patterns that might help explain the variance in perceptions.

\section{$4 \quad$ Method}

In order to explore what kind of climate-related environmental changes people in Tuvalu, Samoa, and Tonga perceive and expect, a structured interview guideline with open and closed questions was designed to obtain qualitative as well as quantitative results. The distinction between current perceptions and expectations was made in order to learn which changes individuals consider most relevant for their current situation and for their future. Moreover, this approach helps to match the results with scientific observations and projections.

The survey started with questions regarding socio-demographic information. Then, the participants were asked to list all environmental changes they could remember, future environmental changes they expect, and the causes they consider relevant to these changes. Subsequent to this qualitative section, quantitative ques- 
tions were asked to capture the perceptions of more specific environmental changes including changes of weather, seasons, plants, and the marine environment. The survey took place from February 2011 to February 2012. The survey templates were translated into Tuvaluan, Samoan, and Tongan languages, and the interviews were conducted by local research assistants. Answers were noted in the vernaculars and then translated into English by the research assistants.

The responses to the qualitative questions differ in the degree of detail they provide: while some participants just mentioned a keyword, others portrayed their perceptions in greater depth. The categories that were used for the analysis are therefore divided into main topics and more specific details (Table S1-S7 in the supplementary information available online). The quantitative, closed questions all had a similar structure of 7-point Likert scales. A first set of scales reached from -3 to +3 , and depending on the wording of the question, the ends of the scales were 'less' - 'more', 'lower' - 'higher', or 'worse' - 'better'. Zero in the middle of theses scales stood for 'no change'. A second set of scales reached from 0 to 6 , and had the end points 'don't agree' - 'agree strongly', 'no changes' - 'big changes', or 'not at all' - 'severely'.

In order to investigate relations of perceptions with several socio-demographic characteristics, we conducted mainly correlation analyses for ordinal data (Spearman Rho). Here, we tested for age, gender, number of inhabitants of the settlements that people live in, distance to the sea, house and land ownership, interaction with nature, education, socio-economic status, and religiosity. ${ }^{1}$ In preparation for the correlation analyses, factor analyses were performed for the dependent and independent variables. There were considerable overlaps in the factor structures of the three countries, yet they were not identical. Based on the information retrieved from the factor analyses, composite variables were calculated for rain, wind and storms, flooding with sea water, and marine life (Table S12). For the independent variables, factor analyses for religiosity showed a two-factor structure which can be interpreted as self-assessment of religiosity and the number of church-related activities.

\subsection{Sample}

For each country, the local research assistants were asked to conduct interviews with 60 individuals in different places close to the sea. As we did not aim for a representative sample because of economic restrictions, but for gaining comparative insights into perceptions of inhabitants of different island states, we decided

\footnotetext{
${ }^{1}$ The survey also contained a short scale about climate change knowledge consisting of ten yes/no questions which were planned to be summed up as a knowledge score. However, observed answer patterns led to the assumption that these questions were not differentiating enough to provide a sufficient measure. Although such scales are common (e.g. van der Linden, 2015; Leiserowitz et al., 2010), the answer format allows for a high chance of guessing right. We therefore refrained from using this scale for further analyses.
} 
on an ad hoc sample and on leaving the selection of interviewees to the research assistants. The research assistants received the same instructions for selecting participants for the survey and were asked to interview participants living close to the sea in smaller and larger settlements, covering a broad range with regard to age, education, and income, as well as equal numbers of male and female participants.

Table 3: Summary of sample characteristics

\begin{tabular}{|c|c|c|c|}
\hline $\begin{array}{l}\text { Sample } \\
\text { Characteristics }\end{array}$ & Tuvalu & Samoa & Tonga \\
\hline $\begin{array}{l}\text { Time of inter- } \\
\text { view }\end{array}$ & May-June 2011 & February 2012 & February-March 2011 \\
\hline $\begin{array}{l}\text { Participants by } \\
\text { Island }\end{array}$ & $\begin{array}{l}47(79.7 \%) \text { Funafuti } \\
12(20.3 \%) \text { Vaitupu }\end{array}$ & $\begin{array}{l}58(96.7 \%) \text { Upolu } \\
2(3,3 \%) \text { missing }\end{array}$ & $\begin{array}{c}20(33.9 \%) \text { Lifuka } \\
39(65.0 \%) \text { Tongatapu } \\
1(1.7 \%) \text { missing } \\
\end{array}$ \\
\hline Gender & $\begin{array}{lc}\text { Female } & 24(40.7 \%) \\
\text { Male } & 33(55.9 \%) \\
\text { Missing } & 2(3.4 \%)\end{array}$ & $\begin{array}{lc}\text { Female } & 36(60.0 \%) \\
\text { Male } & 24(40.0 \%) \\
\text { Missing } & 0(0 \%)\end{array}$ & $\begin{array}{lc}\text { Female } & 41(68.3 \%) \\
\text { Male } & 19(31.7 \%) \\
\text { Missing } & 0(0 \%)\end{array}$ \\
\hline Age (years) & \begin{tabular}{llll} 
M & \multicolumn{2}{c}{63.57} & \\
SD & 11.69 & & \\
Min & $35 \quad$ Max & 86 \\
Missing & 1
\end{tabular} & $\begin{array}{lll}M & 33.25 & \\
\text { SD } & 17.50 & \\
\text { Min } 16 \quad \text { Max } & 84 \\
\text { Missing } & 1 & \end{array}$ & $\begin{array}{llll}M & 46.00 & \\
S D & 12.56 & & \\
\text { Min } & 24 & \text { Max } & 72 \\
\text { Missing } & 1 & & \end{array}$ \\
\hline $\begin{array}{l}\text { Size of the set- } \\
\text { tlement } \\
\text { (Number of } \\
\text { inhabitants) }\end{array}$ & $\begin{array}{ll}M & 660.42 \\
S D & 441.26 \\
\text { Min } 8 \quad \text { Max } 2000 \\
\text { Missing } 16\end{array}$ & $\begin{array}{l}\text { M } 1802.29 \\
\text { SD } 1608.12 \\
\text { Min } 10 \quad \text { Max } 5000 \\
\text { Missing } 9\end{array}$ & $\begin{array}{l}M \quad 572.50 \\
\text { SD } 504.87 \\
\text { Min } 150 \quad \text { Max } 2000 \\
\text { Missing } 0\end{array}$ \\
\hline $\begin{array}{l}\text { Distance from } \\
\text { home to the sea } \\
\text { (meters) }\end{array}$ & $\begin{array}{ll}\text { M } 112.29 \\
\text { SD } 175.4 \\
\text { Min } 10 \quad \text { Max } 1250 \\
\text { Missing } 1\end{array}$ & 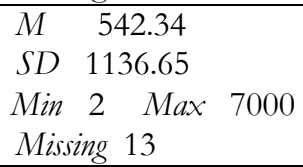 & 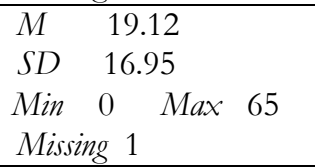 \\
\hline $\begin{array}{l}\text { House and } \\
\text { land } \\
\text { ownership }\end{array}$ & $\begin{array}{lr}\text { Yes } & 45 \\
\text { No } & 12 \\
\text { Missing } & 2 \\
\end{array}$ & $\begin{array}{lr}\text { Yes } & 52 \\
\text { No } & 1 \\
\text { Missing } & 7 \\
\end{array}$ & $\begin{array}{lr}\text { Yes } & 29 \\
\text { No } & 29 \\
\text { Missing } & 2 \\
\end{array}$ \\
\hline $\begin{array}{l}\text { Plant for } \\
\text { own daily con- } \\
\text { sumption }\end{array}$ & $\begin{array}{llll}\text { Yes } & 40 & \text { Sell* } & 7 \\
\text { No } & 19 & & \\
\text { Missing } & 0 & & \\
\end{array}$ & $\begin{array}{llll}\text { Yes } & 30 & \text { Sel* } & \\
\text { No } & 28 & & \\
\text { Missing } & 2 & & \\
\end{array}$ & $\begin{array}{llll}\text { Yes } & 28 & & \\
\text { No } & 32 & & \\
\text { Missing } & 0 & & \\
& & \\
\end{array}$ \\
\hline $\begin{array}{l}\text { Fish for } \\
\text { own daily } \\
\text { consumption }\end{array}$ & $\begin{array}{llll}\text { Yes } & 35 & & \\
\text { No } & 24 & & \\
\text { Missing } & 0 & & \\
\text { Mis } & & \\
\end{array}$ & $\begin{array}{llll}\text { Yes } & 10 \\
\text { No } & 48 & \text { Sell* } & \\
\text { Missing } & 2 & \end{array}$ & 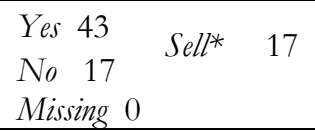 \\
\hline
\end{tabular}

* number of people who sell their farming produce or catch

For Tuvalu, the majority of interviews were held on Funafuti, while a smaller number were conducted on Vaitupu (Table S19). All participants from the Samoan sample were from Upolu (Table S20). And two thirds of the Tongan sample came 
from the main island of Tongatapu, while one third was from Lifuka (Table S21). A comparison of perceptions of different communities within the three countries was not planned. Table 3 summarises the socio-demographic features and also highlights specific differences between the samples: for instance, whereas the Tuvaluan sample shows a mean value for age of 64 years, the Tongan and Samoan samples are relatively young with mean values of 46 years and 33 years respectively. Also, the size of settlements and distance to the sea show considerable variance; however, this can be attributed to the specific characteristics of islands and settlements. Questions about dependency on natural resources for daily life (i.e., if respondents grow their own food and catch fish for their daily consumption) received quite similar answers. Yet, for the Samoan participants, it is striking that only a few respondents engage in fishing activities. This might be explained by the fact that most individuals in the sample are rather young and comparatively highly educated university students. Despite these differences in the sample characteristics, the results provide valuable insights into how individuals from different island states perceive climate-related environmental changes and their causes.

4.2 Severe weather events occurring shortly before and during the time of the survey

In addition to long-term climatic changes, short-term variability and extreme events are likely to affect perceptions of climate related environmental changes as they can be seen as key events with the potential to convince individuals that something might be unusual about the climate that they have been familiar with so far (Howe, Markowitz, Ming-Lee, Ko, \& Leiserowitz, 2012; Zaval, Keenan, Johnson, \& Weber, 2014; Myers, Maibach, Roser-Renouf, Akerlof, \& Leiserowitz, 2013). Extreme events also set people's awareness into a state of alarm and when they occur more frequently than usual, they might be seen as proof of climate change.

The studied regions have suffered from several extreme events. For example, during the time of the survey from February 2011 to February 2012, La Niña had a considerable effect on local weather patterns. On September 28, 2011, the government of Tuvalu declared a state of emergency because of severe water shortages, but Samoa and Tonga also suffered from a lack of rainfall during that time.

In addition, the following tropical cyclones have hit the region since the year 2000, and thereby might have had an effect on recent perceptions: Vaka in 2001; Heta at the turn of the year 2003-04; Tam, Urmil, and Vaianu in 2006; Lin in 2009; Wilma in 2011; and Jasmine in 2012. Heavy wind and rain affect not only the abiotic environment in terms of destruction and erosion, but also plants and plantations that need time to recover and to be replanted. 


\section{$5 \quad$ Results}

\subsection{Perceptions of climate-related environmental change}

In general, based on the overview of mean values and standard deviations in Figure 1 , each country shows a distinct profile. ${ }^{2}$ In all three cases, most of the future environmental changes are expected to be more intense than present ones. Large standard deviations for most items indicate that perceptions are not homogenous but show considerable variance (see also Figure S1 in the supplementary information available online). In addition, most items turned out to be not normally distributed, but either bimodal or skewed to one direction. One more characteristic feature of the quantitative data includes the relatively high percentages of missing values which is particularly striking for the data of future expectations (Figure S1). The following paragraphs report the perceptions of climate-related environmental changes based on the analysis of the qualitative and quantitative data for weather and seasons, the abiotic environment, and impacts on biological systems.

\section{Changes in weather and seasons}

The most commonly perceived changes with regard to weather and seasonality include (i) increases in temperature in all three countries, (ii) changes in rainfall patterns, and (iii) changes in wind patterns and storm events. Furthermore, changes in seasons and predictability of weather were described by participants of all three island states.

Increases in temperature or "increased heat of the sun" were highlighted consistently by most participants in their replies to the open questions about environmental changes. Looking at the quantitative results, perceived temperature increases are particularly notable in Tuvalu and Samoa. Changes in temperature were also reported by most Tongan participants in the qualitative section and also reach high levels of agreement in the quantitative part.

Changes in rainfall are perceived differently in the three countries. Respondents from Tuvalu emphasised the lack of rain and severe drought conditions in their replies to the open questions. In Samoa, people described both extremes, i.e. too little and too much rain. And in Tonga, the experience and expectation of heavy rainfall were more prevalent than the experience and expectation of lack of rain. These results are reflected in the quantitative data. Drought was among the most prominently noted changes in Tuvalu and Samoa. With regard to rain frequency and intensity, Tongan respondents agreed strongly about increasing trends for each. Participants from Samoa only saw and expected increases in rain intensity, whereas there is no clear tendency to either direction in the quantitative data from Tuvalu.

\footnotetext{
${ }^{2}$ Additional figures and tables S1-21 are available in the supplementary information available online.
} 


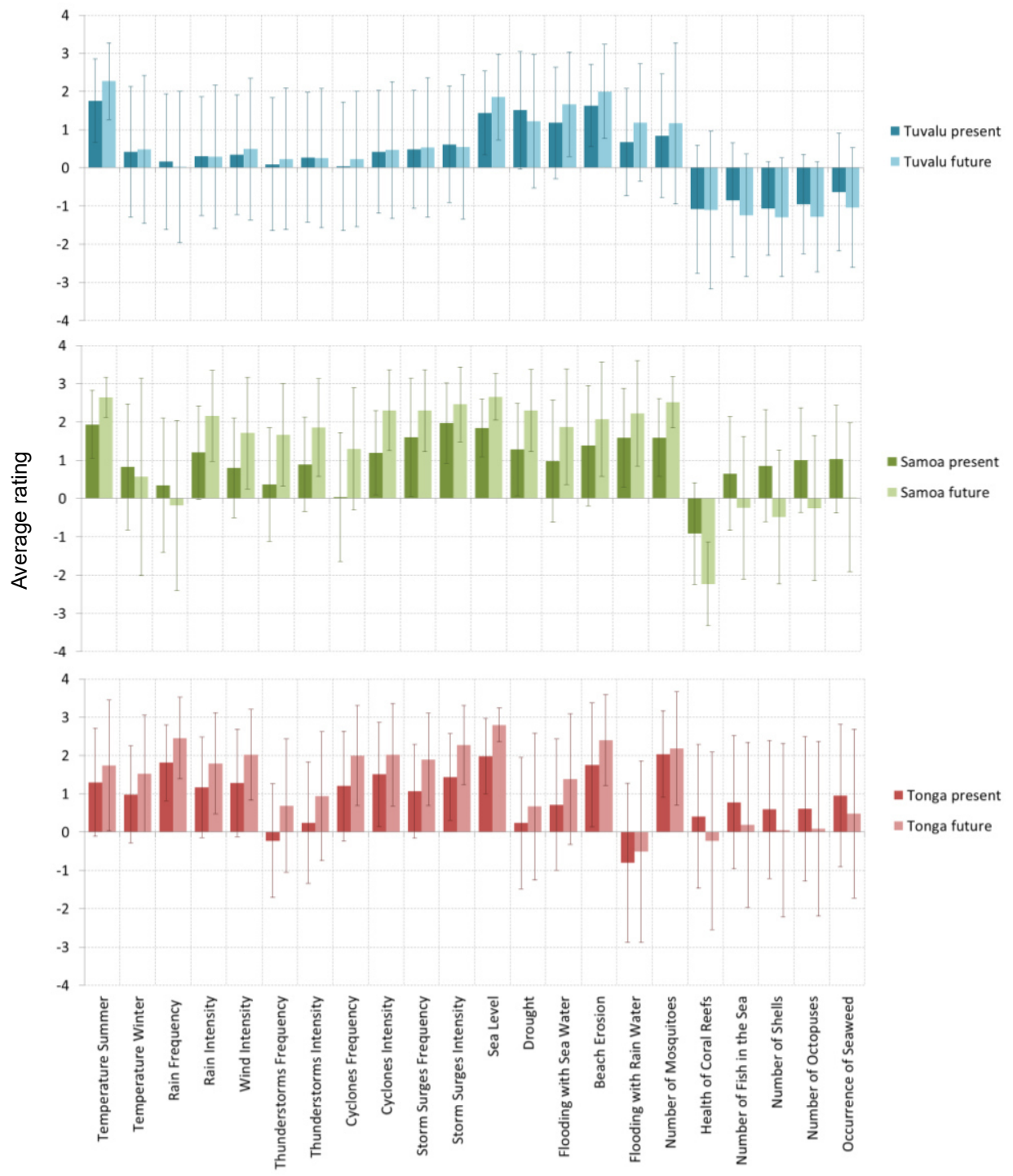

Figure 1: Country profiles for mean values and standard deviations of the perception of climate-related environmental changes (for details see S1)

With regard to changes of wind, replies reveal that in Samoa and Tonga the focus lies mainly on the occurrence of tropical cyclones. Although some respondents from Tuvalu reported winds to be stronger, more frequent, and more unpredictable in the open questions, the quantitative results did not capture these perceptions. However, the results for the Tongan and Samoan participants are consistent with the qualitative data. Participants from Tonga agreed strongly that cyclones have 
become more frequent and intense, whereas Samoan respondents experienced cyclones as being more intense rather than being more frequent. For the future, Samoans and Tongans expect increases in both frequency and intensity of tropical cyclones.

Generally, respondents from all three countries reported that seasons and weather patterns are changing, have become irregular, and have become more unpredictable. Extended and warmer hot seasons were mainly described by the Tuvaluan and Tongan participants. Also, longer dry seasons and droughts were mentioned frequently, particularly by the Samoan sample. In addition, participants were asked to name the months of the beginnings and ends of wet and dry seasons, hot and cooler seasons, and the cyclone season for the past and for the present. Looking at the specific months for the beginnings and endings of seasons, two observations can be made (Figure S2): First, for the past, the participants had a pretty clear notion of when seasons used to begin and end. Second, perceptions of the beginnings and endings of seasons have shifted slightly.

\section{Abiotic environment}

Changes in the abiotic environment that are related to alterations in climate and weather include, on the one hand, sea level rise that is experienced and expected in all three countries, and on the other hand, the effects of too much and too little rain, namely flooding and droughts.

With regard to sea level rise as one of the most prominent changes noted in island contexts, qualitative and quantitative results are consistent. Only two respondents of the whole sample stated explicitly in the qualitative part that there is no sea level rise, and only $5 \%$ of the Tuvaluan sample and even less in the other two groups said in the quantitative section that they experience and expect slightly lower sea levels (Figure S1). According to the replies to the two specific quantitative questions about present and future height of the sea level, the overwhelming majority experiences and expects higher sea levels. This change is experienced as leading to increased flooding with sea water, erosion, and salt water intrusion. Beach erosion is perceived and expected as severe, with more than half of the respondents of each sample expecting medium and strong increases in beach erosion for the future. The experience and expectation of flooding with sea water is most prominent in Tuvalu though, where king tides are a known disruptive phenomenon. In Tonga, sea water flooding is related to storm surges and increased wave height associated with tropical cyclones.

In addition to the impacts of sea level rise, flooding with rain water is experienced particularly in Tonga and Samoa as leading to soil erosion and causing landslides. However, the quantitative data only reflects these experiences as being widespread in Samoa, and less so in the Tongan sample, where the majority said they experience and expect a decrease in rain water flooding. Whereas heavy precipitation is occasionally described as having positive effects of filling up water resources, the 
Tuvaluan respondents focused mainly on the impacts of too little rainfall, i.e. dried up soils and water resources having crucial impacts on the biotic environment.

\section{Biotic environment: plants and animals}

The vast majority of participants from all three countries perceive and expect changes in plants. Respondents reported perceptions about less, unhealthy, or dying trees, impaired coastal vegetation, loss of medicinal and traditional plants, as well as effects of changing weather and seasons on fruits and vegetables. Specifically mentioned species are pulaka (giant swamp taro, Cyrtosperma merkusii or Cyrtosperma chamissonis), taro, yams, and cassava, which are all important root crops and staple foods. Furthermore, other locally relevant species were named, such as coconut, breadfruit, banana, mango, pandanus, potato, cucumber, and pawpaw. Most of the fruits and vegetables were described as being smaller or not growing in season. Occasionally, the occurrence of new grasses, invasive species, and more weeds was mentioned.

Results from the qualitative data show that in all three countries changes and effects on terrestrial animals are perceived and expected. These changes were mainly described on a general level, not naming specific species. Some Samoan participants mentioned the effects of deforestation on habitat loss and increased consumption of animals by humans. Sometimes, specific animal species were named, such as pigs, chickens, other birds, and bats. In Samoa and Tonga, the increase of mosquitoes was reported a few times, mostly as a result of heavy rain and flooding. The quantitative data did not cover the change of terrestrial animals except for the number of mosquitoes. Although mosquitoes were not mentioned explicitly in the qualitative responses, the mean values for the Samoan and Tongan samples are so high that they are even among the top five environmental changes noted within the quantitative data results.

Despite the proximity to and dependency on marine environments, these ecosystems received surprisingly little attention compared to effects on terrestrial plants and animals in the replies to the general open questions. However, in all three countries, changes of marine life were mentioned, mostly the decrease of fish and shellfish, and impacts on coral reefs. These changes were predominantly described in connection with increased temperatures, but also as results of human activities like pollution, coral and sand mining, land reclamation, as well as destructive fishing practices and overfishing. The quantitative data about marine life shows diverging patterns for each country. Particularly Tuvaluan respondents agreed that the health of coral reefs, the number of fish in the sea, the number of shellfish and octopuses, and also the occurrence of seaweed have decreased, and they expected them to further decrease in the future. For the Samoan sample, the perception and the future expectation of the health of coral reefs are rather sinister; and although perceived numbers of fish, shellfish, octopuses, and seaweed were described as having increased until the time of the interviews, decreases were expected for the 
future. The Tongan participants varied in their replies, and expect little increase in marine organisms.

\subsection{Attributed causes for change}

According to the qualitative results (Tables S9-S11), most participants see buman activities as the main cause of the changes they described. Looking closer at the details, these include pollution, mainly air pollution due to burning of rubbish and plastic, use of fossil fuels, and release of greenhouse gases (GHGs). Mentioned sources of GHGs (specifically carbon dioxide and methane) are the use of cars, motorbikes, motorboats, and trucks, burning in general - in particular wood, chemicals, steel, and aluminium - and cooking gas. ${ }^{3}$ Furthermore, modern technologies and machines, factories, and industries within the country and in "wealthy countries", as well as the introduction of inorganic products were brought up as reasons by individuals from the Tuvaluan and Samoan samples. The use of chemicals and dumping of (toxic) wastes and litter were mentioned as additional causes for change.

In general, respondents, particularly in Tuvalu and Samoa, referred to an overuse, abuse, or unwise use of resources. Irresponsible and selfish behaviour of not taking care of the environment were mentioned along with valuing money more than the consequences of such behaviours, economic activities, greed, and modernisation. Changed conservation and consumption patterns, societal changes, bad manners of the youth, and new religious denominations came up in the explanations as well. Furthermore, population growth, overpopulation, and migration were named in this context. With regard to modern technologies, people from Tuvalu sometimes pointed out the role of advancing knowledge and the work of scientists as reasons for change.

Several respondents of each country also referred to natural processes as reasons for the environmental changes. In addition, other processes, such as global warming, climate change, ozone depletion, UV radiation, melting ice of North and South Pole, as well as El Niño occurred in the explanations mostly in connection with increased amounts of (greenhouse) gases and deforestation. Moreover, higher temperatures, increased heat of the sun, drought, strong winds, sea level rise, and erosion appeared in the explanations of reasons, not always, but often put in connection with each other. However, compared to the answers which related directly to human activities described above, these phenomena were mentioned without naming a specific anthropogenic contribution.

A few respondents from all three countries also see God as the main reason for the environmental change they perceive, sometimes God alone, sometimes as pun-

\footnotetext{
${ }^{3}$ Here, it becomes apparent that explanations were occasionally rather specific and do not necessarily meet standard scientific explanations - although in a wider sense, such activities could be seen as contributing to climate change. Also, gas of refrigerators was named, which probably refers to chlorofluorocarbon (CFC).
} 
ishment for the irresponsible human behaviour, sometimes also in connection with natural processes.

These results are also reflected in the answers to the quantitative closed questions (Figure 2). Most respondents agreed that humans and air pollution caused by modern human lifestyle are the reasons for the changes of weather and seasons, and disagree that human activities have no significant impact or that God or other spirits cause these changes.

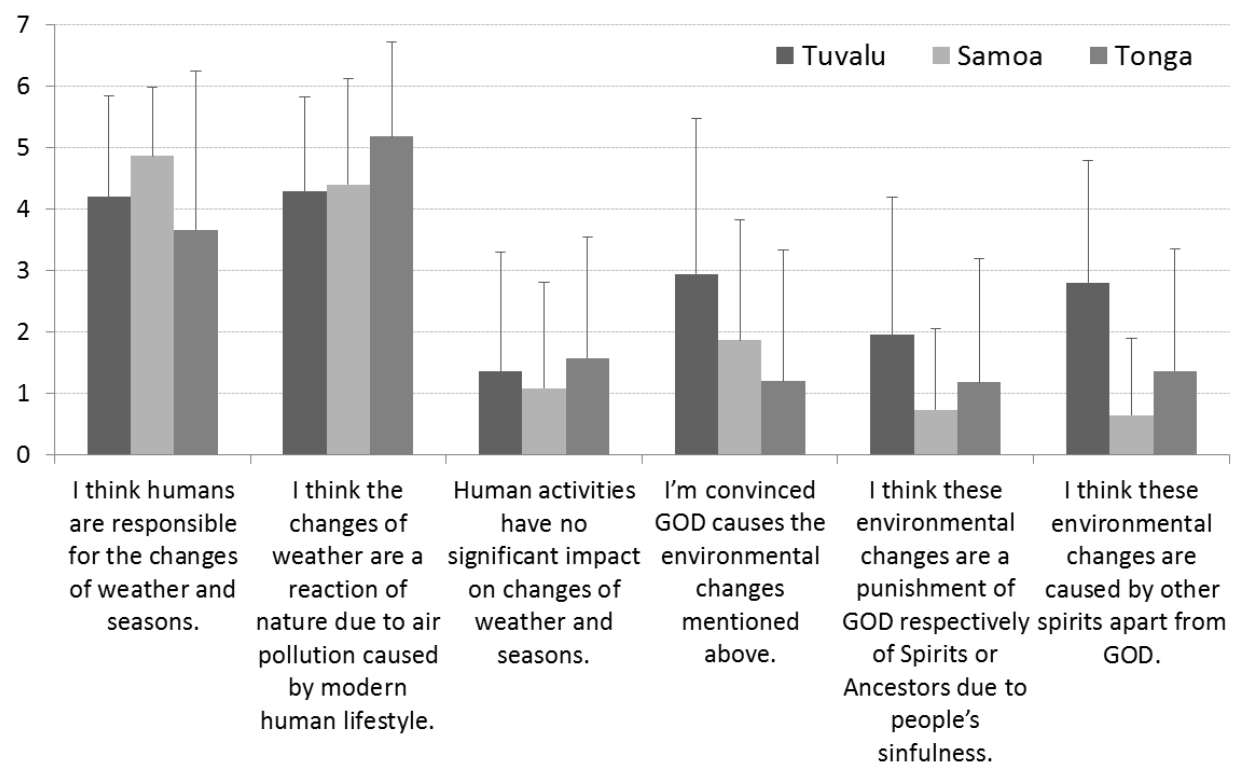

Figure 2: Mean values and standard deviations for the agreement to statements about causes for the perceived environmental change

\subsection{Correlational analyses of the variance in perceptions}

Reporting each correlation in detail here would go beyond the scope of this paper. Therefore, only significant ( $\mathrm{p} \leq 0.05$, two-sided) correlations and patterns will be highlighted and are illustrated in Figure 3 (for detailed information see also Tables S13-S18 and Figure S4 in the supplementary information available online). Several socio-demographic variables do not correlate significantly and consistently with the quantitative perception data over all three samples. These include age, years spent on the island, gender, house ownership, and education. However, four of the selected variables are more frequently significantly correlated with environmental perceptions: (i) the size of the settlement in which the respondents live, (ii) the distance to the sea, (iii) interaction with nature, and (iv) religiosity. Interesting here is that the perceived changes that are correlated with these variables differ between the three countries, so it is not possible to say, for instance, that people who farm 
or garden for their own daily diet consistently perceive more changes in plants than those who do not plant, or those who fish perceive changes in marine life more uniformly. 4



Figure 3: Significant ordinal correlations (Spearman Rho, $\mathrm{p} \leq \mathbf{0 . 0 5}$, two-sided) between socio-demographic variables and perceived climate-related environmental changes; red symbols illustrate significant positive correlations, blue symbols stand for significant negative correlations

\section{Size of settlements}

Although the patterns of correlations are not consistent, they show that the size of the settlement that people live in seems to play an important role when it comes to the perception of environmental changes. For example, Tuvaluan respondents living in smaller settlements perceive and expect significantly more changes in seasons, but less increase in temperature, rain, and wind compared to people in larger settlements. The Samoan sample shows a different pattem: people in smaller settlements perceive increases in temperature, rain, storms, sea level, and flooding,

\footnotetext{
${ }^{4}$ The correlations of these four variables with the perception data are also rather small, supporting the assumption that other factors should be included and tested in order to determine potential reasons for the variance in perceptions. The current findings serve as anchor points for the generation and testing of more detailed hypotheses.
} 
whereas individuals in larger agglomerations perceive more changes in seasonality. Tongan participants living in larger settlements perceive stronger increases in rain, drought, and flooding with rain water than those in rural areas.

\section{Distance to the sea}

The distance to the sea shows patterns that are in line with what could be expected, since the risk of sea water flooding is objectively lower inland: participants who live further away from the sea perceive less sea level rise, especially in Samoa, and less flooding with sea water in Samoa and Tonga. In Tonga, however, people living further away from the sea perceive increased flooding with rain water, and better conditions of marine resources compared to people living closer to the shore.

\section{Interaction with nature}

Several significant correlations reoccur for the variables regarding regular interaction with nature in terms of farming and fishing for subsistence, as well as for the self-assessment of the connectedness to nature of daily job activities (see also Figure S4). For instance, people in Samoa who reported selling their farming produce, fishing for their daily diet, or also selling the fish they catch perceive increased droughts, more winds and storms, as well as increased flooding with sea water. Tongan respondents who farm or garden for their daily diet perceive significantly fewer droughts, less flooding with rain water, fewer mosquitos, and greater decrease of marine resources compared to people who do not. Tongan participants who fish perceive an increase in changes of plants. Interestingly, fishing and farming activities are not related to significant correlations that would match the respective ecosystem that fishers (marine resources) or farmers (plants) interact with. We find similar results for the Tuvaluan respondents.

\section{Religiosity}

The self-assessment of religiosity and the amount of self-reported church-related activity are significantly correlated with several perceptions of environmental changes: respondents from Samoa who describe themselves as very religious perceive greater increases in temperature, sea level, and flooding with sea water than people who report being less religious. Tongan individuals who assess themselves as more religious than others perceive higher temperatures, as well as increases in rain, storms, and flooding with rain water. In Tuvalu, the opposite is the case: here people who score high in religious self-assessment perceive and expect less wind and more changes in seasons and plants compared to people who assess themselves as less religious. For the number of self-reported church-related activities, the picture is similar except for the Tongan sample. Tuvaluans who describe them- 
selves as very active church members perceive and expect less rain, less wind, and greater changes of seasons compared to people who say they attend church and pray less often. Individuals from the Samoan sample with high scores on the church-related activity scale, however, perceive and expect more rain, wind, and flooding with sea water than people who go to church less often. ${ }^{5}$

\section{Discussion}

This study set out to explore the diversity of perceptions of climate-related environmental changes and attributed causes in samples from Tuvalu, Samoa, and Tonga. The results reveal that respondents from all three countries do perceive various changes, and expect that most of the observed trends will intensify in the future. Main causes for the reported changes are seen in irresponsible and unsustainable human behaviours. The results of our explorative study provide some indications of the underlying reasons for the variance in perceptions; however, further studies testing specific hypotheses with a more representative sample are recommended.

In this section, the results are discussed against the backdrop of natural science observations. Furthermore, we address attributed causes and the variance in perception of climate change. We close our discussion with methodological considerations.

\subsection{Comparing perceptions and observations}

Comparable to diverse in-depth studies about the perception of environmental changes from other countries, changes have been reported for weather and seasonality, sea level and flooding, as well as impacts on plants and animals for the three studied samples from Tuvalu, Samoa, and Tonga (see Savo et al., 2016). Among the changes which many respondents from all three samples perceived as most intense are higher temperatures, altered seasonal patterns, rising sea level, increases in beach erosion, and sea water flooding.

With regard to a comparison between the three countries, it is particularly interesting that the majority of participants in the Tuvaluan sample perceive the in-

\footnotetext{
${ }^{5}$ Partial correlation analyses controlling for number of inhabitants, showed that for daily activities in nature and religious self-assessment the significant correlation patterns change slightly, but not fundamentally. However, for religious church-related activities, most of the significant correlations disappeared, indicating that people in smaller settlements take part in more church-related activities, so hardly any explanatory power was left to the variable with regard to the perception of environmental change. Religious self-assessment yet seems to maintain as a variable explaining some variance in the perception of climate-related environmental changes. The fundamental processes underlying this effect should still be investigated further for Pacific Island communities.
} 
creased occurrence of drought to be among the greatest challenges, whereas most individuals in the Samoan and Tongan samples perceive and expect increases in rain and storms. Although sea level rise is often considered as the most prominent climate-related environmental change for small island states, this change is actually only one among many others that were reported. Changes with immediate impacts on daily life, such as tropical cyclones and extreme precipitation that lead to flooding on the one hand, or long periods with no rain that cause a lack of fresh water on the other hand, are equally if not even more relevant to people's daily lives. This result highlights the importance of a more holistic approach that focuses on sustainable development instead of adaptation to climate change only (Barnett \& Campbell, 2010; McMillen et al., 2014; Barnett \& Waters, 2016).

In addition, changes were described for plants, numbers of mosquitoes, and marine life. These findings reflect geographical and climatic differences as well as tendencies reported in previous studies from the region (e.g. Lazrus, 2015; Aswani et al., 2015). Although we are aware that there are always local specificities for each country and community, we base our comparison with natural science observations on data at the country level. This approach results from the distribution of the survey participants in different places of each country (Tables S19-S21) as well as the scarce availability of local natural science data at the community-level.

Comparing the perceptions with meteorological measurements and future projections from the Australian Bureau of Meteorology and CSIRO $(2014,2011)$ makes apparent that although the significant trends of climate-related changes are relatively small and hardly discernible with human sensation, the perceived alterations are consistent with regional trends for temperature and other climate parameters. With regard to meteorological data for precipitation, annual and seasonal rainfall trends for the period of 1950-2009 have not been statistically significant yet, although more intense and frequent extreme rain events are projected for the future. The perceived increases in rain intensity (in the case of the Samoan and the Tongan sample) and increased rain frequency (in the Tongan sample) can therefore probably be linked to short term observations - an effect that has similarly been found by Howe et al. (2012) and Zaval et al. (2014). Climate models also project a slight decrease of future drought events for the region, being consistent with the expectations of participants from Tuvalu, but not with those from Samoa. The projections that tropical cyclones will be less frequent but more intense in the future (see Meehl et al., 2007) is in accordance with the perceptions of Tongan and Samoan participants in the case of cyclone intensity; and although many respondents expect cyclone frequency to increase as well, the mean values for expected cyclone strength are still higher than those for expected frequency.

Concerning abiotic changes, perceptions of sea level rise and erosion are also in line with scientific observations (Australian Bureau of Meteorology \& CSIRO, 2014, 2011; Becker et al., 2012). With regard to erosion, particularly data from Tuvalu shows that shorelines are dynamic by nature (Webb \& Kench, 2010). Since coastal dynamics always need to be seen in connection with human activities, the 
increase of erosion that has been described by the participants proves to be consistent with observations from other locations (Yamano et al., 2007; Webb \& Kench, 2010; Lata \& Nunn, 2012).

Also, the perceptions of biotic changes of marine and terrestrial flora and fauna can be related to scientific observations, although more detailed research would be desirable. The questions about the development of marine life were very simple in this study, following the intention to capture a general trend in perceptions rather than attempting to represent the biodiversity of the Pacific Ocean. Marine resources face several stressors, including over-harvesting of some fish stocks and invertebrates, pollution, sedimentation, and coastal development particularly in more densely populated areas (Chin et al., 2011; Morrison, Denton, Bale Tamata, \& Grignon, 2013). This matches the perceptions of the Tuvaluan sample, especially those of participants living in larger settlements. In addition to such stressors, other phenomena that challenge Pacific reef stability include severe storms, tsunamis, volcanic activity, coral bleaching, ocean acidification, and outbreaks of crown-ofthorns sea stars. In the case of Samoa, the reefs were observed to have recovered after Cyclone Heta in 2004; therefore, perceptions of increases in marine resources match the scientific observations (Chin et al., 2011). For the future, rising water temperatures and acidification pose serious threats to marine resources, hence, the extent to which positive outlooks expressed by the Tongan sample match scientific projections is questionable. However, these expectations could possibly also refer to near future developments and reef recovery after cyclone Wilma that hit Tonga in 2011. Future studies might therefore investigate further how individuals expect specific marine resources to develop and what kind of parameters guide those expectations.

Impacts of climate-related and anthropogenic changes on plants match diverse regional scientific observations (Harter et al., 2015). Such changes not only have consequences for food security, but also affect cultural practices (Wairiu, Lal, \& Iese, 2012; Thaman, Gregory, \& Takeda, 2011; Thaman, 2014). Although developments of plants were captured only by the qualitative questions regarding general environmental changes and two rather unspecific closed questions in this study, the results show that impacts on flora are perceived. Further studies could help to identify changes and their consequences more precisely for specific species and thereby help to inform strategies for adaptation. ${ }^{6}$

With regard to future expectations, the number of missing values (S1) can be interpreted in the sense that participants find it difficult to estimate and picture future developments. This information should not be neglected but taken seriously

\footnotetext{
${ }^{6}$ Finally, the perceptions of increased numbers of mosquitoes in Samoa and Tonga can be related to the time of the survey in February and March following months with heavy rainfalls known to stimulate mosquito reproduction. Interestingly, Harding et al. (2007) found larval habitat to be more abundant in towns than in rural areas, matching the future expectations of mosquito developments at least for Samoa.
} 
when it comes to the communication and planning of adaptation strategies. Often, scientists try to avoid missing values or 'don't know' options in surveys because they make statistical analyses more difficult (Rubin, 2004). Therefore, it might be surprising that in comparison to other survey studies we highlight this 'flaw' which in our opinion contains valuable information: when people are not sure about what to expect, they might not be motivated to take specific precautionary measures. Hence, it is important to foster the dialogue about the potential consequences of current lifestyles that are likely to lead to hazardous environmental change.

\subsection{Causes for environmental change}

The explanations that people described as causing these changes also show that most respondents attribute them to human actions. Although God's will, work, plans, and decisions were mentioned occasionally as causes as previously reported in other studies (Lata \& Nunn, 2012; Mortreux \& Barnett, 2009; Rudiak-Gould, 2014; Kuruppu \& Liverman, 2011), replies often highlighted careless and unsustainable human behaviour and resulting pollution. Albeit not always correctly described from a scientific perspective, most respondents are generally aware of multiple causes for many environmental changes (see Hay, 2013). In order to receive more specific replies, it would be necessary to ask for each perceived environmental change individually to investigate mental models of causes and effects. Here, a comparison between public and expert views would be interesting. However, the results already generally highlight the awareness of an anthropogenic contribution to environmental change. This opens up ways for further dialogue about necessary transformations to more sustainable lifestyles.

For such a dialogue and awareness raising to occur it is crucial to consider local modes and means of communication. In our study we found that that observation and radio are important sources of information in all three samples (Figure S3). Church and talks in the community also reach high rankings in Tuvalu and Tonga. However, the rather young and comparatively well-educated people in the Samoan sample also said they get a lot of information from TV, school or university, and the internet. Here, traditional sources of information seem to become less relevant. Hence, in order to be as accessible and inclusive as possible, awareness campaigns and public dialogue about sustainable lifestyles and environmental change should be adapted to the preferred modes of communication.

\subsection{Variance in perceptions}

Perceptions of climate-related environmental changes vary both between and within island states. Although this statement seems trivial, the empirical foundation based on the same method for the comparison of different samples was still lacking. The current study, therefore, introduces a method to scan perceptions and provide an overview of the most relevant changes. Moreover, it helps to compare 
perceptions and future expectations. This contrast is relevant for adaptation planning: people who do not expect the aggravation of a situation or a specific damage are likely to be less motivated to take proactive precautions. Also, individuals who overestimate certain issues might invest in adaptation measures that experts would not really consider high priority.

In addition to the described differences between the samples of the three countries (see section 6.1 above), perceptions of climate-related environmental changes also vary within the samples. Here, the selected socio-demographic variables account for a certain fraction of the total variance in the results. As in other studies from the region and elsewhere, factors like age, sources of information, size and location of settlements, interaction with nature, and religiosity correlate with perceptions of climate-related environmental changes (Nunn et al., 2016; Scott-Parker, Nunn, \& Mulgrew, 2016; Lata \& Nunn, 2012; Rudiak-Gould, 2014; Brody, Zahran, Vedlitz, \& Grover, 2008; Milfont et al., 2014). In particular, we identified four variables that stand out in terms of showing more frequent significant correlations to the environmental perceptions, namely, (i) the size of the settlement that the respondents are living in, (ii) the distance to the sea, (iii) interaction with nature, and (iv) religiosity. The first three variables and their correlations with the perception of changes in weather and nature reflect an experiential factor: direct personal experience with environmental systems affects the perception of change (see Reser et al., 2014; van der Linden, 2015; Weber, 2016).

However, we have to be careful about interpreting such effects, as these variables might be indicators for other underlying factors that shape the perceptions of climate-related environmental change. (i) The size of the settlement that people live in is likely to be an indicator for the effect that individuals in more urban areas might be confronted with different sources of information, might perceive more pollution and environmental stress due to higher population densities, and lead less subsistence-oriented lifestyles than their rural counterparts. (ii) The observation that the distance to the sea affects the perception of maritime changes, sea level rise, and flooding with sea water corresponds with psychological distance (Milfont, 2014; McDonald, 2015). (iii) The effect of interaction with nature would need to be tested further, not only to distinguish who perceives changes more accurately, but also to determine the extent to which access to media or other factors might modulate the perceptions of climate-related environmental changes. In addition, the correlations of the socio-demographic variables with one another (intercorrelations) hamper a sound, integrative interpretation. Therefore, it would be advisable in addition to this explorative survey, to set up further studies that set out to test individual hypotheses either with small, specific samples or large, representative ones. 


\subsection{Methodological considerations}

The perception of climate-related environmental changes might be equally - if not more - relevant for the planning of individual adaptation strategies than beliefs in climate change. In the survey, we asked explicitly about how people perceive weather features and their impacts, and how they think these will evolve in the future. We consciously did not use the terms 'climate change' or 'global change' in order to not reinforce the effect of motivated reasoning on weather perceptions, although it will be hardly possible to circumvent it completely (Reser et al., 2014; Taylor, Dessai, \& Bruine de Bruin, 2014; Myers et al., 2013). We did so because perceptions of environmental changes and their causes are likely to shape people's expectations about future developments to a certain degree, and might therefore inform specific adaptation behaviour more specifically than beliefs about the rather abstract concept of climate change (Leiserowitz et al., 2016; Spence Poortinga, \& Pidgeon, 2012; Lorenzoni \& Pidgeon, 2006). Even in the Pacific, it has been found that 'climate change' is considered as affecting others more severely than oneself (Nunn et al., 2016), and therefore, more specific environmental changes that are already experienced are likely to be more imaginable. In addition, vernacular translations for 'climate' have been found to relate to other meanings, for instance 'weather' (Dumaru, 2010), or air, space, and the atmosphere (Rudiak-Gould, 2012) and would introduce extra biases.

\section{$7 \quad$ Conclusion}

Overall, the study explores, quantifies, and compares perceptions and expectations of climate-related environmental changes in three PSIS. Based on the overview of perceptions and factors that help explain the variance between individuals, this study provides an explorative basis of quantitative and qualitative data for the further development and testing of specific hypotheses in PSIS. In doing so, the study offers a report that goes beyond anecdotal evidence of how climate-related environmental changes are perceived by the affected populations in PSIS (Betzold, 2015). The survey instrument that has been developed can be used for follow-up studies and for gathering comparable data in other countries.

The most pronounced perceptions that we found for our three samples refer to rises in temperature, high levels of beach erosion, rising sea levels, an increase in storm activity, and changes in flora and fauna. The data from our study confirm that sea level rise, which is often seen as the most prominent climate-related environmental change, is only one change among many others that have been reported. In particular changes with immediate impacts on daily life, such as tropical cyclones, extreme precipitation, and drought are equally if not even more relevant to people's daily lives.

Based on empirical evidence, we can show that perceptions of climate-related environmental changes vary within and between the samples of the three PSIS. To 
a certain extent, this variation can be attributed to differences in local weather conditions and geographical specificities. Lee et al. (2015, p. 1014) found in a survey of 119 countries that "understanding the anthropogenic cause of climate change is the strongest predictor of climate change risk perceptions, particularly in Latin America and Europe, whereas perception of local temperature change is the strongest predictor in many African and Asian countries". In our three samples, many respondents perceived a local temperature change, and were highly aware of anthropogenic causes for change. Levels of awareness of environmental change can thus be assumed to be relatively high not only among young, urban respondents, as reported, for instance, in the study by Scott-Parker et al. (2016) or Lata and Nunn (2012), but also within the broader population.

In addition to geographical specificities that explain a certain fraction of the variance in perceptions, the role of psychological factors deserves further investigation. In the current study, we explored to what extent the variance in perceptions can be related to socio-demographic factors and found several significant correlations. Based on these insights, we suggest investigating the role of additional factors, such as value orientations, social norms, affect, and past experience which proved to be relevant determinants for the perception of climate change risk and also local weather in other regions of the world (van der Linden, 2015; Goebbert, Jenkins-Smith, Klockow, Nowlin, \& Silva, 2012).

One of the most practically relevant findings is that many respondents are generally aware of multiple causes of the reported alterations, and mainly attribute them to human behaviour. Although the survey results are rather general in this respect, they offer a basis for identifying prevailing modes of unsustainable behaviour that call for change. Here, it would be necessary to study specific cause-effect relationships and compare them to expert views. Such a comparison could help to set up a societal and transdisciplinary dialogue on the necessity of sustainable lifestyles and management decisions. As people witness the unintended consequences of behaviours and consumption patterns that have found their way to the islands in the course of modernisation, building on their perceptions can help to foster a dialogue on how to develop and mainstream alternative, sustainable behavioural options that would equally fulfil the intended purposes.

\section{Acknowledgement}

This work was supported by the German Research Foundation (DFG Research Training Group GRK 780/III), The German Academic Exchange Service (D/10/43472), and The Faculty of Science, Technology and Environment at The University of the South Pacific.

The authors thank the local research assistants and the people from Tuvalu, Samoa, and Tonga. We further thank our colleagues at the Department of Geography at The University of the South Pacific and at Humboldt Universität Berlin. 
We are grateful for the support of the Institute of Advanced Sustainability Studies as well as the Pacific Centre for Environment and Sustainable Development. In particular, we thank Wilfried Endlicher, Ludwig Ellenberg, Randy Thaman, Camari Koto, Viliamu Iese, Mark Lawrence, Ortwin Renn, Stefan Schäfer, Pia-Johanna Schweizer, Ilan Chabay, Jürgen Finster, Tim Butler, Oliver Putz, and the families Tawake, Whippy, and Pratap.

\section{Bibliography}

Aswani S., Vaccaro I., Abernethy K., Albert S., \& Fernandez J. (2015). Can perceptions of environmental and climate change in island communities assist in adaptation planning locally? Environmental Management, 56(6), 1487-1501.

Australian Bureau of Meteorology \& CSIRO (2011). Climate change in the Pacific: Scientific assessment and new research. Volume 1: Regional overview. Volume 2: Country reports.

Australian Bureau of Meteorology \& CSIRO (2014). Climate variability, extremes and change in the Western Tropical Pacific: New science and updated country reports. PacificAustralia Climate Change Science and Adaptation Planning Program. Technical Report, Australian Bureau of Meteorology and Commonwealth Scientific and Industrial Research Organisation, Melbourne, Australia.

Barnett, J., \& Campbell, J. (2010). Climate change and small island states: Power, knowledge and the South Pacific. London: Earthscan.

Barnett, J., \& Waters, E. (2016). Rethinking the vulnerability of Small Island States: Climate change and development in the Pacific Islands. In Grugel, J., and Hammett, D. (Eds.), The Palgrave Handbook of International Development (pp 731748. London: Palgrave Macmillan.

Becker, M., Meyssignac, B., Letetrel, C., Llovel, W., Cazenave, A., \& Delcroix, T. (2012). Sea level variations at tropical Pacific islands since 1950. Global and Planetary Change, 80-81, 85-98.

Betzold, C. (2015). Adapting to climate change in small island developing states. Climatic Change, 133(3), 481-489.

Beyerl, K., Putz, O., \& Breckwoldt, A. (2016). The role of perceptions in community-based marine resource management. Frontiers of Marine Science, 3(238).

Beyerl, K., Mieg, H.A., \& Weber, E. (2018). Comparing perceived effects of climate-related environmental change and adaptation strategies for the Pacific small island states of Tuvalu, Samoa, and Tonga. Island Studies Journal, 13 (1), 25-44.

Bord, R.J., Fisher, A., \& O’Connor, R.E. (1998). Public perceptions of global warming: United States and international perspectives. Climate Research, 11, 75-84.

Brechin, S.R. \& Bhandari, M. (2011). Perceptions of climate change worldwide. WIREs Climate Change, 2, 871-885. 
Brody, S.D., Zahran, S., Vedlitz, A., \& Grover, H. (2008). Examining the relationship between physical vulnerability and public perceptions of global climate change in the United States. Environment and Behavior, 40 (1), 72-95

Capstick, S. B., Whitmarsh, L. E., Poortinga, W., Pidgeon, N. F., \& Upham, P. (2015). International trends in public perceptions of climate change over the past quarter century. WIREs Climate Change, 6 (1), 35-61.

Chin, A., Lison De Loma, T., Reytar, K., Planes, S., Gerhardt, K., Clua, E., Burke, L., \& Wilkinson, C. (2011). Status of coral reefs of the Pacific and outlook: 2011. Global Coral Reef Monitoring Network.

Dumaru, P. (2010). Community-based adaptation: Enhancing community adaptive capacity in Druadrua Island, Fiji. WIREs Climate Change, 1, 751-763.

Farbotko, C. (2010). Wishful sinking: Disappearing islands, climate refugees and cosmopolitan experimentation. Asia Pacific Viewpoint, 51(1), 47-60.

Goebbert, K., Jenkins-Smith, H. C., Klockow, K., Nowlin, M.C., \& Silva, C. L. (2012). Weather, climate, and worldviews: The sources and consequences of public perceptions of changes in local weather patterns. Weather, Climate, and Society, 4, 132-144.

Green D., Billy J., \& Tapim A. (2010). Indigenous Australians' knowledge of weather and climate. Climatic Change, 100(2), 337-354.

Grothmann, T. (2005). Klimawandel, Wetterextreme und private Schadensprävention. Entwicklung, Überprüfung und praktische Anwendbarkeit der Theorie privater Wetterextrem-Vorsorge (Doctoral dissertation, University of Magdeburg).

Grothmann, T., \& Patt, A. (2005). Adaptive capacity and human cognition: The process of individual adaptation to climate change. Global Environmental Change, 15(3), 199-213.

Harding, J., Brown, C., Jones, F. C., \& Taylor, R. (2007). Distribution and habitats of mosquito larvae in the Kingdom of Tonga. Australian Journal of Entomology, 46, 332-338.

Harter, D. E. V., Irl, S. D. H., Seo, B., Steinbauer, M. J., Gillespie, R., Triantis, K.A., Fernández-Palacios, J.-M., \& Beierkuhnlein, C. (2015). Impacts of global climate change on the floras of oceanic islands - Projections, implications and current knowledge. Perspectives in Plant Ecology, Evolution and Systematics, 17(2), 160-183.

Hay, J. E. (2013). Small island developing states: Coastal systems, global change and sustainability. Sustainability Science, 8, 309-326.

Howe, P., Markowitz, E. M., Ming-Lee, T., Ko, C.-Y., \& Leiserowitz, A. (2012). Global perceptions of local temperature change. Nature Climate Change, 3(4), 352-356.

Keener, V. W., Marra, J. J., Finucane, M. L., Spooner, D., \& Smith, M. H. (Eds.) (2012). Climate change and Pacific Islands: Indicators and impacts. Report for The 2012 Pacific Islands Regional Climate Assessment. Washington, DC: Island Press. 
Kuruppu, N., \& Liverman, D. (2011). Mental preparation for climate adaptation: The role of cognition and culture in enhancing adaptive capacity of water management in Kiribati. Global Environmental Change, 21 (2), 657-669.

Lata, S., \& Nunn, P. (2012). Misperceptions of climate-change risk as barriers to climate-change adaptation: A case study from the Rewa Delta, Fiji. Climatic Change, 110(1-2), 169-186.

Lazrus, H. (2009). Weathering the waves: Climate change, politics, and vulnerability in Twvalu (Doctoral dissertation, University of Washington, Department of Anthropology).

Lazarus, H. (2015). Risk perception and climate adaptation in Tuvalu: A combined cultural theory and traditional knowledge approach. Human Organization, 74(1), $52-61$.

Lee, T. M., Markowitz, E. M., Howe, P. D., Ko, C.-Y., \& Leiserowitz, A. A. (2015). Predictors of public climate change awareness and risk perception around the world. Nature Climate Change, 5, 1014-1020.

Leiserowitz, A., Maibach, E., Roser-Renouf, C., Feinberg, G., \& Rosenthal, S. (2016). Climate change in the American mind: March, 2016. New Haven, CT: Yale Program on Climate Change Communication.

Leiserowitz, A., Smith, N., \& Marlon, J. R. (2010). Americans' knowledge of climate change. New Haven, CT: Yale Program on Climate Change Communication. .

Lorenzoni, I., \& Pidgeon, N. F. (2006). Public views on climate change: European and USA perspectives. Climatic Change, 77, 73-95.

Marx, S. M., Weber, E. U., Orlove, B. S., Leiserowitz, A., Krantz, D. H., Roncoli, C., \& Phillips, J. (2007). Communication and mental processes: Experiential and analytic processing of uncertain climate information. Global Environmental Change 17, 47-58.

McDonald, R. I, Chai, H. Y., \& Newell, B. R. (2015). Personal experience and the 'psychological distance' of climate change: An integrative review. Journal of Environmental Psychology, 44, 109-118.

McMillen, H. L., Ticktin, T., Friedlander, A., Jupiter, S. D., Thaman, R., Campbell, J., Veitayaki, J., Giambelluca, T., Nihmei, S., Rupeni, E., Apis-Overhoff, L., Aalbersberg, W., \& Orcherton, D. F. (2014). Small islands, valuable insights: Systems of customary resource use and resilience to climate change in the $\mathrm{Pa}$ cific. Ecology and Society, 19(4), 44.

Meehl, G. A., Stocker, T. F., Collins, W. D., Friedlingstein, P., Gaye, A. T., Gregory, J. M., Kitoh, A., Knutti, R., Murphy, J. M., Noda, A., Raper, S. C. B., Watterson, I., Weaver, A. J., \& Zhao, Z.-C. (2007). Global climate projections. In S. Solomon, D. Qin, M. Manning, Z. Chen, M. Marquis, K. B. Averyt, M. Tignor and H. L. Miller (Eds.), Climate Change 2007: The physical science basis. Contribution of Working Group I to the Fourth Assessment Report of the Intergovernmental Panel on Climate Change. Cambridge: Cambridge University Press.

Milfont, T. L., Evans L., Sibley, C. G., Ries, J., \& Cunningham, A. (2014). Proximity to coast is linked to climate change belief. PLoS ONE, 9(7), e103180. 
Milfont, T. L., Milojev, P., Greaves, L., \& Sibley, C. G. (2015). Socio-structural and psychological foundations of climate change beliefs. New Zealand Journal of Psychology, 44, 17-30.

Morrison, R. J., Denton, G. R. W., Bale Tamata, U., \& Grignon, J. (2013). Anthropogenic biogeochemical impacts on coral reefs in the Pacific Islands -An overview. Deep-Sea Research II, 96, 5-12.

Mortreux, C., \& Barnett, J. (2009). Climate change, migration and adaptation in Funafuti, Tuvalu. Global Environmental Change, 19, 105-112.

Myers, T. A., Maibach, E. W., Roser-Renouf, C., Akerlof, K., \& Leiserowitz, A. (2013). The relationship between personal experience and belief in the reality of climate change. Nature Climate Change, 3(4), 343--347.

Nunn, P. D. (2009). Responding to the challenges of climate change in the Pacific Islands: Management and technological imperatives. Climate Research, 40, 211-231.

Nunn, P. D. (2013). The end of the Pacific? Effects of sea level rise on Pacific Island livelihoods. Singapore Journal of Tropical Geography, 34, 143-171.

Nunn, P., \& Kumar, R. (2018). Understanding climate-human interactions in Small Island Developing States (SIDS): Implications for future livelihood sustainability. International Journal of Climate Change Strategies and Management, 10 (2), 245-271.

Nunn, P. D., Mulgrew, K., Scott-Parker, B., Hine, D. W., Marks, A. D. G., Mahar, D., \& Maebuta, J. (2016). Spirituality and attitudes towards Nature in the Pacific Islands: Insights for enabling climate-change adaptation. Climatic Change, 136 (3), 477-493.

Nurse, L. A., McLean, R. F., Agard, J., Briguglio, L. P., Duvat-Magnan, V., Pelesikoti, N., Tompkins, E., \& Webb, A. (2014). Small islands. In V. R. Barros, C. B. Field, D. J. Dokken, M. D. Mastrandrea, K. J. Mach, T. E. Bilir, M. Chatterjee, K. L. Ebi, Y. O. Estrada, R. C. Genova, B. Girma, E.S. Kissel, A. N. Levy, S. MacCracken, P. R. Mastrandrea, and L. L. White (Eds.), Climate Change 2014. Impacts, adaptation, and vulnerability. Part B: Regional aspects. Contribution of Working Group II to the Fifth Assessment Report of the Intergovernmental Panel on Climate Change. Cambridge: Cambridge University Press.

Pidgeon, N. (2012). Public understanding of, and attitudes to, climate change: UK and international perspectives and policy. Climate Policy, 12, 85-106.

Reser, J. P., Bradley, G. L., Glendon, A. I., Ellul, M. C., \& Callaghan, R. (2012). Public risk perceptions, understandings, and responses to climate change and natural disasters in Australia and Great Britain, Gold Coast, Australia. National Climate Change Adaptation Research Facility.

Reser, J. P., Bradley, G. L., \& Ellul, M. C. (2014). Encountering climate change: 'Seeing' is more than 'believing'. WIREs Climate Change, 5, 521-537.

Rudiak-Gould, P. (2012). Promiscuous corroboration and climate change translation: A case study from the Marshall Islands. Global Environmental Change, 22, 46-54. 
Rudiak-Gould, P. (2014). The influence of science communication on indigenous climate change perception: Theoretical and practical implications. Human Ecology, 42, 75-86.

Rubin, D. B. (2004). Multiple imputation for nonresponse in surveys. New York: John Wiley \& Sons.

Savo,V., Lepofsky, D., Benner, J. P., Kohfeld, K. E., Bailey, J., \& Lertzman, K. (2016). Observations of climate change among subsistence-oriented communities around the world. Nature Climate Change 6, 462-473.

Scott-Parker, B., Nunn, P. D., Mulgrew, K., Hine, D. W., Marks, A. D. G., Mahar, D., \& Tiko, L. (2016). Pacific Islanders' understanding of climate change: Where do they source information and to what extent do they trust it? Regional Environmental Change, 17(4), 1005-1015.

Secretariat of the Pacific Community. (2018). 2018 Pocket statistical summary. Pacific Community Noumea, New Caledonia.

Secretariat of the Pacific Regional Environment Programme (SPREP). (2016). State of conservation in Oceania: Regional report 2013. Apia, Samoa: SPREP.

Spence, A., Poortinga, W., \& Pidgeon, N. (2012). The psychological distance of climate change. Risk Analysis, 32 (6), 957-972.

Taylor, A. L., Dessai, S., \& Bruine de Bruin, W. (2014). Public perception of climate risk and adaptation in the UK: A review of the literature. Climate Risk Management, 4-5, 1-16.

Terry, J. P. (2007). Tropical cyclones climatology and impacts in the South Pacific. New York: Springer Science \& Business Media.

Thaman, R. R., Gregory, M., \& Takeda, S. (2011). Trees of life: A guide to trees and shrubs of The University of the South Pacific, Suva, Fiji. Suva: The University of the South Pacific Press.

Thaman, R. R. (2014). Agrodeforestation and the loss of agrobiodiversity in the Pacific Islands: A call for conservation. Pacific Conservation Biology, 20(2), 180-192.

van der Linden, S. (2015). The social-psychological determinants of climate change risk perceptions: Towards a comprehensive model. Journal of Environmental Psychology, 41, 112-124.

Vedwan, N., \& Rhoades, R. E. (2001). Climate change in the Western Himalayas of India: A study of local perception and response. Climate Research, 19, 109-117.

Wairiu, M., Lal, M., \& Iese, V. (2012). Climate change implications for crop production in Pacific Islands region, food production - Approaches, challenges and tasks. In A. Aladjadjiyan (Ed.), Food Production (pp. 67-85). Rijeka: IntechOpen. Retrieved from http://www.intechopen.com/books/food-productionapproaches-challenges-and-tasks/climate-change-implications-for-cropproduction-in-pacific-islands-region. 
Webb, A. P., \& Kench, P. S. (2010). The dynamic response of reef islands to sealevel rise: Evidence from multi-decadal analysis of island change in the central Pacific. Global and Planetary Change, 72(3), 234-246.

Weber, E. U. (2016). What shapes perceptions of climate change? New research since 2010. WIREs Climate Change, 7, 125-134.

West, C. T., Roncoli, C., \& Ouattara, F. (2008). Local perceptions and regional climate trends on the central plateau of Burkina Faso. Land Degradation and Development, 19, 289-304.

Whitmarsh, L. (2008). Are flood victims more concerned about climate change than other people? The role of direct experience in risk perception and behavioural response. Journal of Risk Research, 11(3), 351-374.

Wolf, J., \& Moser, S. C. (2011). Individual understandings, perceptions, and engagement with climate change: Insights from in-depth studies across the world. WIREs Climate Change, 2(4), 547-569.

Yamano, H., Kayanne, H., Yamaguchi, T., Kuwahara, Y., Yokoki, H., Shimazaki, H., \& Chicamori, M. (2007). Atoll island vulnerability to flooding and inundation revealed by historical reconstruction: Fongafale Islet, Funafuti Atoll, Tuvalu. Global and Planetary Change, 57(3-4), 407-416.

Zaval, L., Keenan, E. A., Johnson, E. J., \& Weber E. U. (2014). How warm days increase belief in global warming. Nature Climate Change, 4, 143-147. 